\title{
Recycling Potential of Waste Di-Isobutyl-Ketone (DIBK) and Recovery of Residual Gold*
}

\author{
W. K. Buah, G. Ofori-Sarpong and A. K. Banson
}

Buah, W. K. Ofori-Sarpong, G. and Banson, A. K. (2010), "Recycling Potential of Waste Di-Isobutyl-Ketone (DIBK) and Recovery of Residual Gold", Ghana Mining Journal, Vol. 12, pp. 43 - 48.

\begin{abstract}
Di-Isobutyl-Ketone (DIBK) has been commonly used in most mining and allied industries to extract gold from aqueous solutions for analytical purposes. In most cases a complexing agent, methyl tricapryl ammonium chloride otherwise called aliquat 336 is added to the DIBK to give a 1\% volume by volume solution. The DIBK containing aliquat 336 is then used to extract gold from aqueous solutions for subsequent analysis using Atomic Absorption Spectrophotometry (AAS). After the AAS analysis the DIBK-aliquat solution containing gold is stored as waste since its disposal is often associated with environmental and health problems. This paper investigated the possibility of using distillation to recover gold contained in the waste generated in Ghana as well as the recycling potential of the distillate (regenerated DIBK). It was established that distillation of the waste DIBK yielded about $92 \%$ distillate leaving a residue of tar, which contained all the gold in the waste. Thermal oxidation of the residue followed by conventional cyanidation of the resulting ash led to gold recovery of 98.97\% and the gold extraction efficiency of the regenerated DIBK compares very well with that of fresh DIBK.
\end{abstract}

\section{Introduction}

Di-isobutyl ketone (DIBK), a colourless liquid with a mild, sweet odour, and moderately toxic to humans by inhalation and ingestion, has a wide application in metals extraction (Vincoli, 1997). The basis of metal extraction using DIBK rests on the principle of solvent extraction where a metal in aqueous solution is extracted into an organic phase followed by separation of the organic phase from the aqueous phase (Acharya, 2006). Extraction of metal ions from solutions using DIBK, which has been mixed with a complexing agent for determination of the metal ion concentration, has been investigated by a number of researchers (Acharya, 2006; Honma, 2003; Bertrand et al., 1993; Murakami and Takada, 1992). Murakami and Takada (1992) studied extraction of nickel in approximately $8 \mathrm{M}$ hydrochloric acid solution with ammonium 1-pyrrolidinecarbodithioate (APCD) into DIBK followed by flame atomic-absorption spectrometry. Bertrand et al. (1993) used a similar APCD-DIBK system to extract traces of Fe, Co, $\mathrm{Ni}$ and $\mathrm{Cu}$ from $\mathrm{ZBLAN}$ fluoride glasses $\left(\mathrm{ZrF}_{4}\right.$, $\mathrm{BaF}_{2}, \mathrm{LaF}_{3}, \mathrm{~A}_{1} \mathrm{~F}_{3}, \mathrm{NaF}$ ) dissolved in a $6 \mathrm{~N}$ solution of $\mathrm{HCl}$. The traces were then back-transferred into aqueous solution to be analyzed by graphite furnace atomic absorption spectrometry.

DIBK has been commonly used in most Ghanaian mining and allied industries to concentrate gold in aqueous solutions for analytical purposes. In most cases a complexing agent, methyl tricapryl ammonium chloride otherwise called aliquat 336 is added to the DIBK to give a $1 \%$ volume by volume solution. The DIBK containing aliquat 336 is then used to extract gold from aqueous solutions for subsequent analysis using Atomic Absorption Spectrophotometry (AAS). After the AAS analysis the DIBK - aliquat solution containing gold is stored as waste since its disposal is often associated with environmental problems. The environmental problems include possible contamination of surrounding environmental media, explosion and fire resulting from accidental spills of the waste.

This paper looks at the possibility of using distillation to recover gold contained in the waste DIBK as well as the recycling potential of the distillate. The significance of this study is three fold; (1) the gold recovered means income generation from the waste, (2) recycling of the distillate is a solution to the problems associated with disposal of the waste, (3) the foreign exchange Ghana utilizes in importation of the chemical would be reduced. The study identified the companies in Ghana that use DIBK in gold extraction processes and quantified the stock of the waste generated by these companies. The quantity of gold locked up in the waste was determined and the possibility of distilling the waste to recover its gold content, as well as the recycling potential of the distillate was established.

\section{Materials and Methods}

\subsection{Field Studies on Generation of Waste DIBK}

The field studies, which took the form of questionnaire administration, covered the activities of com-

\footnotetext{
* Manuscript received January 21, 2010

Revised version accepted October 2, 2010
} 
panies associated with waste DIBK generation, storage, treatment and disposal. The questionnaire were administered to obtain information on companies in Ghana using DIBK in gold extraction processes, volume of the waste accumulated and the average rate of generation of the waste.

\subsection{Sampling and Distillation of the Waste DIBK}

Various types of gold ores are treated in laboratories in Ghana and aqua regia is normally used in digesting the gold. Samples of waste DIBK used in extracting dissolved gold after the digestion process were collected from various laboratories, and mixed to form a composite waste solution.

Experiments involving distillation were carried out to design a technology for gold recovery from the waste and determine the recycling potential of the distillate. A total of $8 \mathrm{~L}$ of the composite waste, assaying 13.49 ppm gold was placed in a flask containing a supporting bed of $1000 \mathrm{~g}$ wood charcoal, and distilled at $160^{\circ} \mathrm{C}$. Before distillation, the char was tested to ensure it contained no gold and its proximate analysis using Shimadzu Thermogravimetric Analyser TGA-50H was also determined to confirm its volatile content and hence ability to sustain autogeneous roasting of the residue (Zhao et al., 1995). The distillation was carried out until no visible liquid waste was observed at the bottom of the flask, and it yielded a distillate and a sticky residue on the wood charcoal.

\subsection{Thermal Oxidation and Mineralogical Analysis of the Distillation Residue}

The distillation residue together with the char was subjected to thermal oxidation in a muffle furnace at $850^{\circ} \mathrm{C}$ until constant weight was achieved. The ash residue was allowed to cool and weighed. Mineralogical/Chemical composition of a representative sample of the ash was carried out using Siemens X-ray diffractometer (XRD) D5000.

\subsection{Cyanidation of the Gold-bearing Ash Resi- due}

A $40 \mathrm{~g}$ representative sample of the gold bearing ash residue was pulverized and pulped to $50 \%$ solids and conditioned to a $\mathrm{pH}$ of 11 by lime addition. The pulped sample was leached in a flask with a 1000 ppm cyanide solution for 21 hours. The content of the flask was continuously stirred during the experiment using a magnetic stirrer. Samples of the leach solution were taken at various time intervals and concentrations of gold in the solution samples determined using a Varian AA240 Fast Sequential Atomic Absorption Spectrophotometer (AAS).

The content of the flask was filtered after the 21 hours of leaching and the residual cyanide concentration was determined by titration with a $0.01 \mathrm{M}$ solution of $\mathrm{AgNO}_{3}$ using rhodamine indicator.

\subsection{Assessment of Gold Extraction Efficiency of the Regenerated DIBK}

Two sets of gold standard solution containing 2.5 ppm and $5.0 \mathrm{ppm}$ gold were prepared by dilution of a 1000 ppm gold standard solution. A $10 \mathrm{ml}$ portion of each of the two standards was mixed with $5 \mathrm{ml}$ of either fresh DIBK or the regenerated DIBK. The mixtures were vigorously shaken for about a minute and allowed to settle. The gold concentration in the organic DIBK phase was determined using AAS.

\subsection{Infrared Spectroscopy of DIBK Samples}

Fresh and regenerated DIBK were sampled from their respective storage containers for Infrared (IR) spectroscopic analysis. The containers were first shaken at $20^{\circ} \mathrm{C}$ to ensure homogeneity before sampling with an Eppendorf Dispenser. The samples were subsequently pipetted into a Fourier Transform Infrared (FTIR) sample cell for analysis. The spectrum obtained after scanning was compared with the Infrared Spectrum Correlation Diagram in Fig. 1. Generally, more attention is paid to the region from 3500 to $1500 \mathrm{~cm}^{-1}$ because the stretching and bending vibrations for most functional groups are found in this region. Vibrations in the region 1500 and $400 \mathrm{~cm}^{-1}$ are much more complex and far more difficult to analyse. Because even slight variations in molecular structure and absorption patterns are most obvious in this region, it is often called the fingerprint region. If two compounds have even slightly different structures, the difference in their infrared spectra is most clearly discernible in this region.

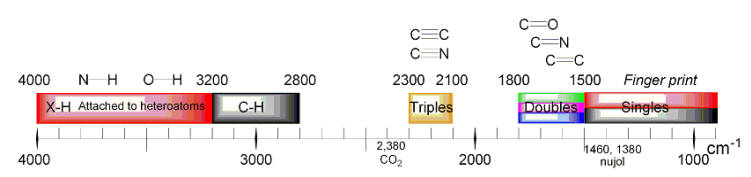

Fig. 1 Infrared Spectroscopy Correlation Dia gram (Source: Griffith and De Haseth, 1986)

\section{Results and Discussion}

\subsection{Waste DIBK Generation and Management}

Information on companies in Ghana using DIBK in gold extraction processes, volume of the waste generated and the average rate of generation of the waste, obtained from questionnaire administration are presented in Table 1 . The results represent the activities by eight mining and allied companies operating in the Tarkwa Municipality, Ghana, whose names are withheld for the sake of confidentiality. These companies represent about 50\% of such companies in Ghana utilizing DIBK in gold extraction for AAS analysis. 
Table 1 Response to Questionnaire Administration

\begin{tabular}{|c|c|c|c|c|c|c|c|c|}
\hline Companies & 1 & 2 & 3 & 4 & 5 & 6 & 7 & 8 \\
\hline $\begin{array}{l}\text { Type of gold ore being } \\
\text { treated }\end{array}$ & Varying & Oxide & Oxide & All types & Oxide & Oxide & Oxide & Oxide \\
\hline $\begin{array}{l}\text { Process used for gold } \\
\text { extraction }\end{array}$ & Analytical & CIP/CIL & $\mathrm{CIP} / \mathrm{CIL}$ & Analytical & $\mathrm{CIP} / \mathrm{CIL}$ & $\mathrm{CIP} / \mathrm{CIL}$ & CIL & CIL \\
\hline $\begin{array}{l}\text { Number of years of } \\
\text { DIBK usage (years) }\end{array}$ & 12 & 17 & 5 & 20 & 5 & 17 & 4.5 & 11.5 \\
\hline $\begin{array}{l}\text { Amount of DIBK } \\
\text { generated in a month } \\
\text { (litres) }\end{array}$ & 105 & 20 & 12 & 200 & 200 & 200 & 10 & 50 \\
\hline $\begin{array}{l}\text { Average grade of gold } \\
\text { in waste DIBK (ppm) }\end{array}$ & 0.45 & 70 & 0.31 & 1.8 & 100 & 25 & 0.8 & 0.3 \\
\hline $\begin{array}{l}\text { Recovery of gold from } \\
\text { waste DIBK }\end{array}$ & $\begin{array}{l}\text { Not } \\
\text { recovered }\end{array}$ & $\begin{array}{l}\text { Not } \\
\text { recovered }\end{array}$ & $\begin{array}{l}\text { Not } \\
\text { recovered }\end{array}$ & $\begin{array}{l}\text { Not } \\
\text { recovered }\end{array}$ & $\begin{array}{l}\text { Not } \\
\text { recovered }\end{array}$ & $\begin{array}{l}\text { Not } \\
\text { recovered }\end{array}$ & $\begin{array}{c}\text { Not } \\
\text { recovered }\end{array}$ & $\begin{array}{l}\text { Not } \\
\text { recovered }\end{array}$ \\
\hline $\begin{array}{l}\text { Mode of storage of } \\
\text { waste DIBK } \\
\end{array}$ & $\begin{array}{c}\text { Stored in } \\
\text { drums }\end{array}$ & $\begin{array}{c}\text { Stored in } \\
\text { drums }\end{array}$ & Not stored & $\begin{array}{c}\text { Stored in } \\
\text { drums }\end{array}$ & $\begin{array}{c}\text { Stored in } \\
\text { drums }\end{array}$ & Not stored & $\begin{array}{l}\text { Stored in } \\
\text { drums }\end{array}$ & Not stored \\
\hline $\begin{array}{l}\text { Mode of disposal of } \\
\text { waste DIBK }\end{array}$ & $\begin{array}{c}\text { Collected by } \\
\text { petroleum } \\
\text { company }\end{array}$ & Burning & Burning & Burning & Burning & \begin{tabular}{|c|} 
Burning into \\
the \\
atmosphere
\end{tabular} & $\begin{array}{l}\text { Burnt with } \\
\text { acetone }\end{array}$ & $\begin{array}{l}\text { Burnt with } \\
\text { enviro- } \\
\text { burner }\end{array}$ \\
\hline
\end{tabular}

It can be estimated from Table 1 that a total of about 128,160 L of the waste DIBK containing $2,601,529 \mathrm{mg}$ of gold has been generated by the operations of the eight companies selected. The field study also showed that none of the companies recycled the waste DIBK but either stored it in drums or burnt it. Although administrative controls including written procedures on working with the chemical are usually put in place to minimize the potential of human exposure, the environment is at risk of exposure during transport, storage, disposal or destruction of the waste. Accidental spills can result in fire, explosion, and possible contamination of the surrounding environmental media.

\subsection{Products of Distillation of the Waste DIBK}

The distillation of $8 \mathrm{~L}$ of the 13.49 ppm gold laden waste DIBK produced a distillate and a sticky residue on the wood char, which was used as a solid support at the bottom of the flask. The condensed distillate, which could be referred to as regenerated DIBK constituted $92 \%$ by weight of the waste which was distilled. AAS analysis of the distillate showed it contained no gold. All the gold in the waste reported in the residue.

The proximate analysis of the wood char is shown in Fig. 2. The results show that the char contained $67.8 \mathrm{wt} \%$ fixed carbon, $4.7 \mathrm{wt} \%$ moisture, $4.0 \mathrm{wt} \%$ ash and a significant proportion of volatile content of $23.5 \mathrm{wt} \%$, which could support autocombustion of the distillation residue. The char was also assayed and found to contain no gold.

\subsection{Composition of the Distillation Residue}

The distillation residue captured onto the char was subjected to thermal oxidation, in which the resi-

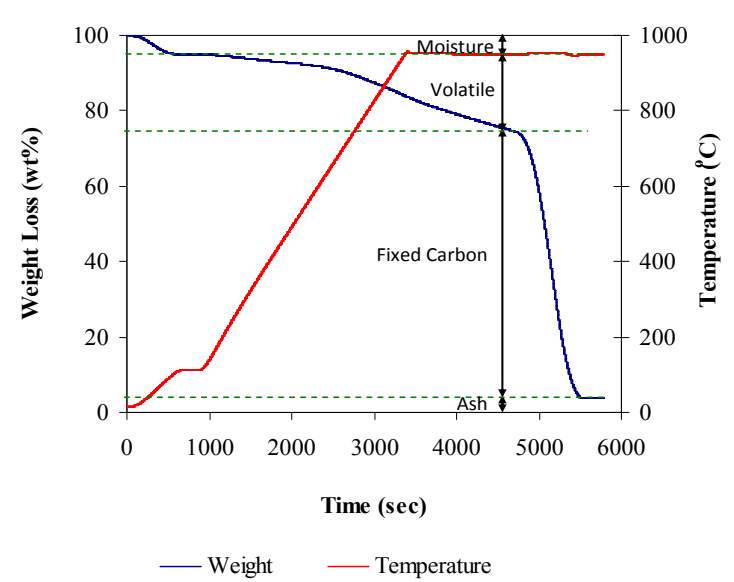

Fig. 2 Proximate Analysis of $20 \mathrm{mg}$ of the Char using Shimadzu Thermogravimetric Analyser

due together with the char solid support was heated to $850^{\circ} \mathrm{C}$ in the presence of oxygen until combustion was complete. The complete oxidation of the residue and the char was necessary to avoid "preg-robbing" of dissolved gold, a situation where unoxidised carbon in the ash would adsorb dissolved gold during cyanidation of the ash (Yannapoulos, 1991; Goodall et al., 2005). The ash sample was allowed to cool down, after which it was weighed. Result of mineralogical/chemical analysis of a representative sample of the ash is shown by the XRD in Fig. 3. The results revealed the presence of Gold $(\mathrm{Au})$, Gold Oxide $\left(\mathrm{Au}_{2} \mathrm{O}_{3}\right)$, Quartz ( $\mathrm{syn}-\mathrm{SiO}_{2}$ ), Maghemite (syn- $\left.\mathrm{Fe}_{2} \mathrm{O}_{3}\right)$, Anorthite, sodian, ordered $\left.(\mathrm{Ca}, \mathrm{Na})(\mathrm{Al}, \mathrm{Si})_{2} \mathrm{Si}_{2} \mathrm{O}_{8}\right)$ and Petedunnite (syn- $\mathrm{CaZnSi}_{2} \mathrm{O}_{6}$ ) as the main minerals in the ash. 


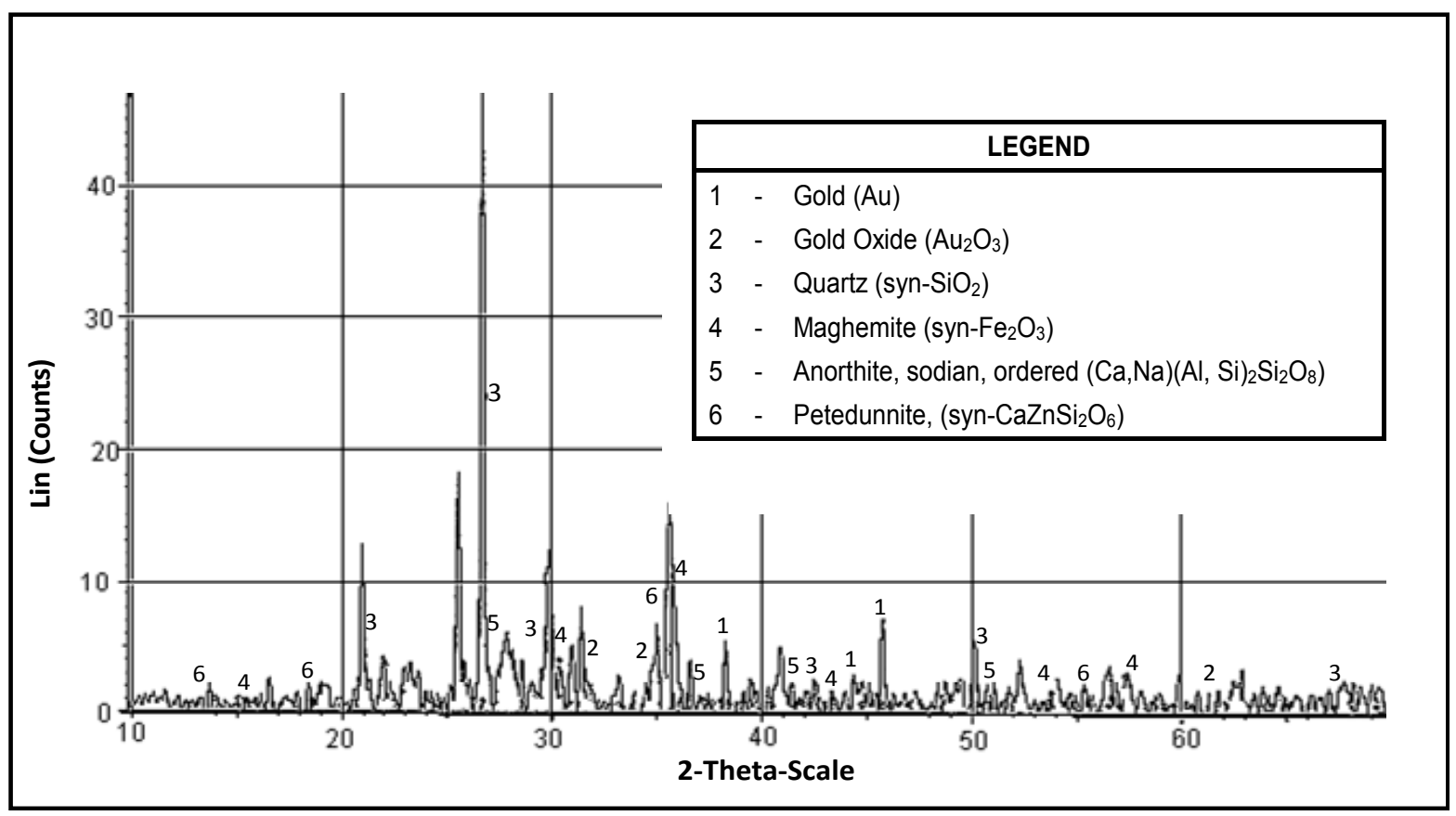

Fig. 3 XRD of the Ash obtained from Combustion of the Distillation Residue/Char Mixture

\subsection{Cyanidation of the Distillation Residue}

Results of cyanidation of the ash residue as shown in Fig. 4 indicate $98.9 \%$ gold extraction after 21 hours of leaching with a 1000 ppm cyanide solution. The results show high recovery of gold from the ash obtained after combustion of the distillation residue. The results of the study demonstrate that a process could be developed to recover gold from the waste DIBK. This process involves distillation of the waste DIBK to obtain a condensed distillate and tar on a solid char support, followed by combustion of the tar/char mixture to produce ash and subsequent cyanidation of the ash to recover gold. The recovery of gold from the waste is a source of income. Cyanide consumption in the form of sodium cyanide during cyanidation of the ash was $0.5 \mathrm{~kg} / \mathrm{t}$.

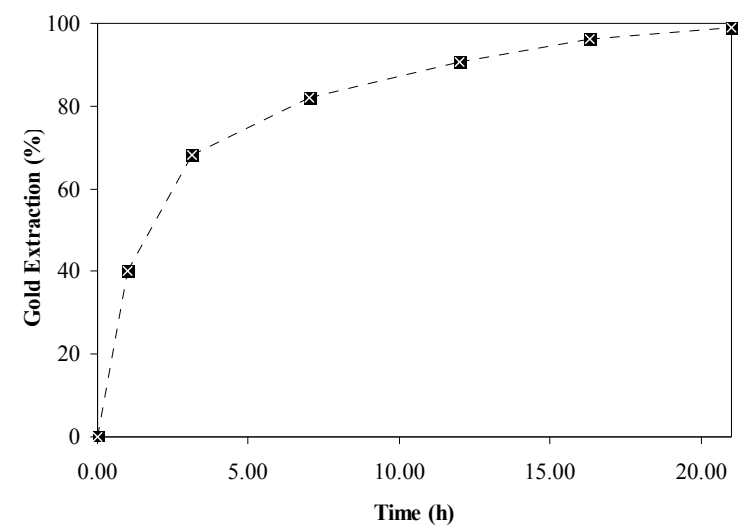

Fig. 4 Gold extraction from the Ash Obtained after Combustion of the Tar/Char Mix ture

\subsection{Extraction Efficiency of the Regenerated DIBK}

Table 2 shows gold extraction efficiency of the regenerated DIBK and that of fresh DIBK. The results show that the gold extraction efficiency of the regenerated DIBK of $98.97 \%$ compares very well with that of the fresh DIBK.

There was excellent reproducibility of the results of gold extraction efficiency using both the fresh and the regenerated DIBK. It is envisaged that recycling of the regenerated DIBK will reduce foreign exchange Ghana utilizes in importation of the chemical and will also reduce the problems associated with storage and disposal of the waste.

\subsection{Infrared Spectroscopy of DIBK}

The FTIR spectrum for fresh DIBK is presented in Fig. 5. Using Fig. 1 as a reference chart, it can be inferred that the main band of the fresh DIBK is made up of the parent ketone corresponding to $\mathrm{C}=\mathrm{O}$ stretching vibrations at $1720 \mathrm{~cm}^{-1}$, the $\mathrm{C}-\mathrm{H}$ chain stretching at $2960 \mathrm{~cm}^{-1}$, the $\mathrm{CH}_{2}$ bending at 1450 and the $\mathrm{CH}_{3}$ bending between $1450 \mathrm{~cm}^{-1}$ and $1360 \mathrm{~cm}^{-1}$. There is a unique finger print between $1500 \mathrm{~cm}^{-1}$ and $400 \mathrm{~cm}^{-1}$ which should identify a diisobutyl group (Griffith and De Haseth, 1986).

It can be deduced from the FTIR spectrum for regenerated DIBK, presented in Fig. 6, that the main band of the regenerated DIBK is made up of the parent ketone corresponding to $\mathrm{C}=\mathrm{O}$ stretching vibrations at $1720 \mathrm{~cm}^{-1}$, the $\mathrm{C}-\mathrm{H}$ chain stretching at $2960 \mathrm{~cm}^{-1}$, the $\mathrm{CH}_{2}$ bending at 1450 and the $\mathrm{CH}_{3}$ bending between 1450 and $1360 \mathrm{~cm}^{-1}$. There is a unique finger print between 1500 and $400 \mathrm{~cm}^{-1}$ 
which should identify a di-isobutyl group. The finger print regions of Figs. 5 and 6 are identical. It can be observed that $\mathrm{CH}_{2}$ bending at $1450 \mathrm{~cm}^{-1}$ and $\mathrm{CH}_{3}$ bending between 1450 and $1360 \mathrm{~cm}^{-1}$ are not significantly modified following the distillation of the spent DIBK. This indicates that the structure of the DIBK is not destroyed and therefore confirms the presence of a 2,6 dimethyl heptan-4-one.

Table 2 Extraction Efficiency of Fresh and Re generated DIBK. Gold from $10 \mathrm{~mL}$ of 2.5 ppm Gold Solution was Extracted into $5 \mathrm{~mL}$ DIBK with $1 \% \mathrm{v} / \mathrm{v}$ Aliquat

\begin{tabular}{|c|c|c|}
\hline \multirow[b]{2}{*}{ Tests } & \multicolumn{2}{|c|}{ Gold extraction efficiency (\%) } \\
\hline & $\begin{array}{c}\text { Fresh DIBK } \\
+1 \% \mathrm{v} / \mathrm{v} \text { aliquat }\end{array}$ & $\begin{array}{c}\text { Regenerated } \\
\text { DIBK } \\
+1 \% \text { v/v aliquat } \\
\end{array}$ \\
\hline I & 98.92 & 98.91 \\
\hline II & 99.03 & 98.98 \\
\hline III & 98.97 & 99.01 \\
\hline Mean & 98.97 & 98.97 \\
\hline $\begin{array}{l}\text { Standard } \\
\text { deviation }\end{array}$ & 0.06 & 0.05 \\
\hline $\begin{array}{l}\text { Relative } \\
\text { standard } \\
\text { deviation }\end{array}$ & 0.06 & 0.05 \\
\hline
\end{tabular}

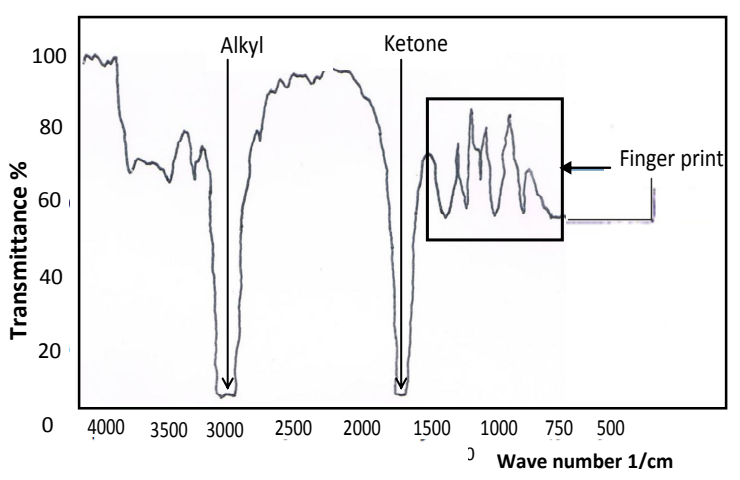

Fig. 5 Fourier Transform Infrared Spectro Graph for Fresh DIBK

In Fig. 6, a new band appears in the region where the ketonic functional group presents its highest intensity band around $1700 \mathrm{~cm}^{-1}$. The difference between the spectrum of the fresh DIBK and the regenerated DIBK is noticeable in the region where the vibrations corresponding to the hydroxyl groups appear (approximately 1600 and $3300 \mathrm{~cm}^{-1}$ ) and this may be attributed to the presence of water.

The intensity is not too pronounced since the amount of the suspected compound on the support is rather small (about $0.01 \%$ water). The most sig- nificant difference between the spectrum of the fresh DIBK and the regenerated DIBK is noticed in the region where the vibration corresponding to the amine groups appears at approximately 3600 $\mathrm{cm}^{-1}$ (Griffith and De Haseth, 1986). This can be identified as traces of the aliquat 336 which is a quaternary amine called tri alkyl methyl ammonium chloride in the spent DIBK. The Infrared Spectroscopic analysis of the fresh and regenerated DIBK indicates they have similar functional groups, which supports their comparable extraction efficiencies.

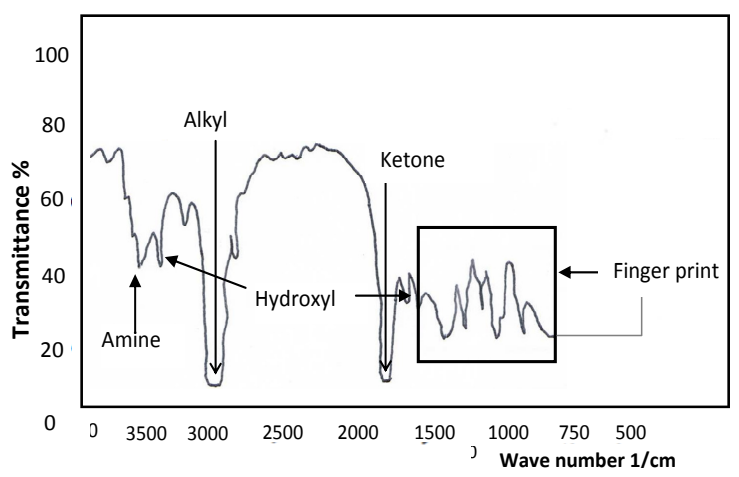

Fig. 6 Fourier Transform Infrared Spectro graph for Regenerated DIBK

\section{Conclusions}

Many Ghanaian mining and allied companies, which carry out gold analysis using DIBK extraction procedures followed by AAS analysis, generate waste DIBK containing gold. The resulting gold laden waste DIBK is mostly stored in drums and not disposed of because of environmental concerns. Distillation of the waste DIBK at $160^{\circ} \mathrm{C}$ on a bed of gold free char as a solid support yielded $92 \%$ distillate, containing no gold and a sticky residue from which gold can be recovered by cyanidation after the residue has been thermally oxidized to produce ash. The distillate was also used for analysis of gold and its extraction efficiency of $98.97 \%$ compares very well with that of the fresh DIBK. This research has demonstrated the recoverability of gold from the waste DIBK and recycling potential of the regenerated DIBK. The recovery of gold from the waste will generate income and recycling of the regenerated DIBK will reduce foreign exchange Ghana utilizes in importation of the chemical and also the problems associated with storage and disposal of the waste.

\section{References}

Acharya, S. (2006), "Molecular interaction in polar -polar system-di-isobutyl ketone (DIBK) and primary aliphatic alcohols-using dielectric measurement", Journal of Molecular Liquids, 
Vol. 124, pp. 68-71.

Bertrand, D., Guery, J. and Jacoboni, C. (1993), "Fe, $\mathrm{Co}, \mathrm{Ni}, \mathrm{Cu}$ trace metal analysis in ZBLAN fluoride glasses", Journal of Non-Crystalline Solids, Vol. 161, pp. 32-35.

Goodall, W. R., Leatham, J. D. and Scales, P. J. (2005), "A new method for determination of preg-robbing in gold ores", Minerals Engineering, Vol. 18(12), pp. 1135-1141.

Griffiths, P. R. and De Haseth, J. A. (1986), "Fourier Transform Infrared Spectroscopy", John Wiley and Sons, New York, New York, pp. 12-23.

Honma, Y. (2003), “One-Pot Speciation Method for $\mathrm{Cr}(\mathrm{III})$ and $\mathrm{Cr}(\mathrm{VI})$ with APCD/DIBK Extraction System Based on Difference in Rate of Complex Formation", Bulletin of the chemical Society of Japan, Vol. 76(7), pp. 1397-1402.

Murakami, M. and Takada, T. (1992), "Application of APCD/DIBK extraction system in strongly acidic media: Determination of traces of copper and nickel in titanium metals by extraction-flame atomic-absorption spectrometry", Talanta, 39(10), pp. 1293-1298.

Vincoli, J. W. (1997), Risk Management for Hazardous Chemicals, Vol. 2, CRC Press, USA, $3136 \mathrm{pp}$.

Yannopoulos, J. C. (1991), The Extractive Metallurgy of Gold. Van Nostrand Reinhold, New York, 281pp.

Zhao, Y., Sun, S., and Zhao, F. (1995), "Recovery of gold from waste carbon", Chinese Patent, 1113961.

\section{Authors}

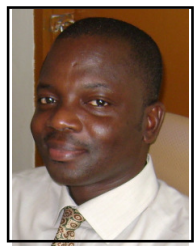

W. K. Buah holds a PhD in Waste Processing Engineering from the University of Leeds, Leeds, UK and MSc in Mineral Processing Engineering from the Mining Institute of Krivoy Rog, Krivoy Rog, Ukraine. He is currently a Senior Lecturer at the University of Mines and Technology, Tarkwa, Ghana. His current research interests include waste management, pyrolysis-gasification of solid waste and biomass to produce valuable products, including activated carbon for gold adsorption, mineral processing and extractive metallurgy. $\mathrm{He}$ is a member of the Society for Mining, Metallurgical and Exploration Engineers (SME).

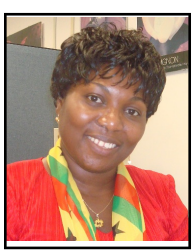

Grace Ofori-Sarpong (Ms) holds a $\mathrm{PhD}$ in Energy and Mineral Engineering from the Pennsylvania State University, an MSc in Environmental Resources Management and BSc in Metallurgical Engineering, both from the Kwame Nkrumah University of Science and Technology, KNUST, Kumasi, Ghana. She is currently a lecturer at the University of Mines and Technology, Tarkwa. Her areas of research interest include water quality monitoring, waste processing, microwaves in extractive metallurgy, bio-modification of recalcitrant organic matter, and small-scale gold mining. She is a member of the Ghana Institution of Engineers (GIE), Society for Mining, Metallurgical and Exploration Engineers (SME), Women in Science and Engineering (WISE) and a fellow of the Schlumberger Faculty for the Future.

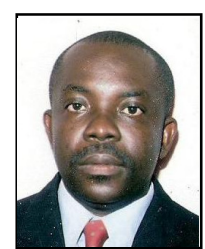

Alex K. Banson holds an MSc degree in Mining Engineering from the Kwame Nkrumah University of Science and Technology, Kumasi and an MBA degree in Strategic and Project Management from the Paris Graduate School of Management, Paris. He is currently an MPhil student in Mineral Engineering at the University of Mines and Technology, Tarkwa. Alex is a life member of the Ghana Quality Organisation and a member of the Ghana Institute of Management. He has practiced extensively as a laboratory manager in West Africa and is currently the managing director of Rhomega Minerals, Ghana. 